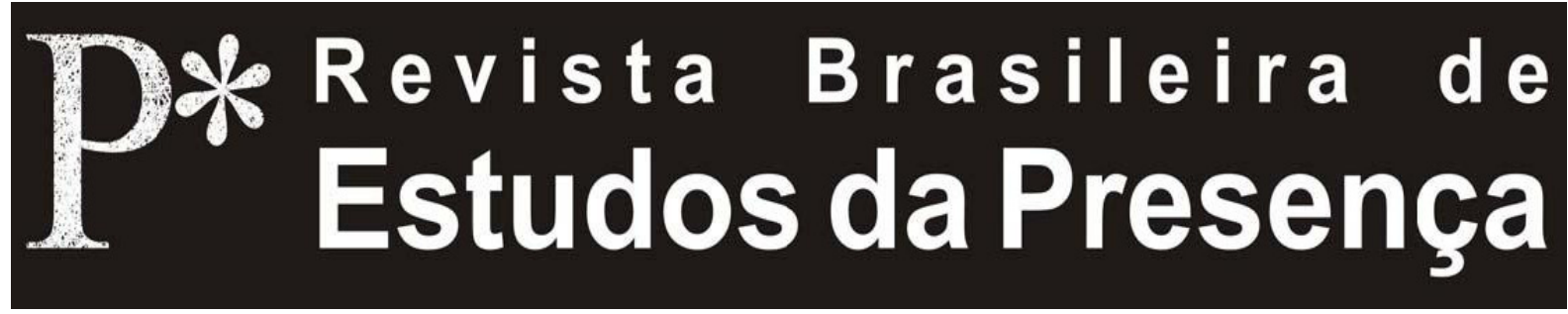

DOI - http://dx.doi.org/10.1590/2237-266033248

ISSN 2237-2660

\title{
O Homem Interior e sua Ação: Jerzy Grotowski e a herança de Adam Mickiewicz e do romantismo polonês
}

Kris Salata

Florida State University - FSU, Estados Unidos da América

RESUMO - O Homem Interior e sua Ação: Jerzy Grotowski e a herança de Adam Mickiewicz e do romantismo polonês - Este artigo coloca Grotowski no contexto cultural concreto do romantismo polonês e na obra do poeta romântico Adam Mickiewicz. O foco principal de análise é a noção de ação e o ato de fazer que desmaterializa a obra de arte, transformando-a em um processo interior - características encontradas nos projetos de Mickiewicz e Grotowski.

Palavras-chave: Mickiewicz. Grotowski. Romantismo. Ação. Trabalho Interior.

ABSTRACT - The Inner Man and his Deed: Jerzy Grotowski and the legacy of Adam Mickiewicz and polish romanticism - This article locates Grotowski in a concrete cultural milieu of Polish Romanticism and of the lifework of the Romantic poet Adam Mickiewicz. The bulk of my focus goes towards the notion of the deed and the act of doing that dematerialises the work of art turning it into an inner process - all features of Mickiewicz's and Grotowski's projects.

Keywords: Mickiewicz. Grotowski. Romanticism. Deed. Inner Work.

RÉSUMÉ - L'Homme Intérieur et son Action: Jerzy Grotowski et l'héritage d'Adam Mickiewicz et du romantisme polonais - Cet article place Grotowski à la fois dans le contexte culturel concret du romantisme polonais et dans l'œuvre du poète romantique Adam Mickiewicz. Le principal axe d'analyse est la notion d'action et l'acte de faire qui dématérialise l'oeuvre d'art, en la transformanat en un processus intérieur - des caractéristiques retrouvées aussi bien dans les projets de Mickiewicz que de Grotowski. Mots-clés: Mickiewicz. Grotowski. Romantisme. Action. Travail Intérieur. 
Uma palavra, a poesia dada através de palavras já é a infelicidade do espírito, que trai a si próprio nela. A palavra escrita demonstra a incapacidade de ação. Para os antigos gregos, a verdadeira poesia significava fazer, Poiesis significa fazer (Mickiewicz, 1955, p. 23).

O Performer, com letra maiúscula, é um homem de ação. Ele não é alguém que representa um outro. Ele é o atuante [...] (Grotowski, 1997, p. 376).

Não existe ser por trás do fazer, do realizar, do devir; $o$ atuante é meramente uma ficção acrescentada à ação. A ação é tudo (Nietzsche, 2000, p. 481).

Em 24 de março de 1997, no palco do Théâtre des Bouffes du Nord, em Paris, um professor recém nomeado do Collège de Fran$c e^{1}$, Jerzy Grotowski, deu sua palestra inaugural intitulada $A$ Linha Orgânica no Teatro e no Ritual. Apesar do prestígio do evento e do grande número de ouvintes, Grotowski chegou com vinte minutos de atraso, vestindo seu terno escuro e amassado de sempre e com uma sacola de viagem no ombro, da qual tirou duas folhas de papel cobertas de anotaçóes e um maço de cigarros, ao qual deu muita atenção. Muitos participantes descrevem a entrada de Grotowski como se ele "houvesse chegado direto do aeroporto" (Rutkowski, 1997; Osiński, 1998, p. 217) ${ }^{2}$, uma imagem com um significado tanto simbólico quanto teórico para um emigrado da Polônia e do teatro, em constante movimento na arte e na vida ${ }^{3}$. O palco do Théâtre des Bouffes du Nord foi iluminado em um único ponto, mostrando uma simples mesa e uma cadeira. Ao saber do extremo cuidado de Grotowski com os mínimos detalhes em eventos públicos, alguns convidados provavelmente acharam difícil acreditar que seu atraso havia sido acidental. Muito consciente do processo de percepção do espectador, o renomado diretor era conhecido por aparecer apenas quando a plateia já estivesse preparada para a sua entrada ${ }^{4}$. Entretanto, devemos lembrar que Grotowski deu suas palestras no Collège de France enquanto lutava com uma doença terminal, a qual ele mantinha em segredo, mas que poderia facilmente ser a causa de seu atraso ${ }^{5}$. Ele falou vagarosamente e com pouca intensidade, mas com paixão, sem pausa, por duas horas, acompanhado apenas pelo silêncio atento dos ouvintes. Ele raramente consultava suas anotaçóes, improvisando sobre a história e a filosofia de sua obra.

Nas suas observaçôes iniciais, Grotowski prestou uma homenagem a Adam Mickiewicz (1798-1855), outro professor polonês do 
Collège de France, que lecionou em Literatura Eslava 150 anos antes. A cadeira de Mickiewicz em Literatura Eslava, assim como a de Grotowski na Antropologia Teatral, fora especialmente criada para ele como um tributo ao bem sucedido artista. De muitas maneiras, a palestra de Grotowski mantinha o espírito da tradição romântica, em especial da sua corrente polonesa representada por Mickiewicz, um poeta, dramaturgo, pensador, místico, orador, e, assim como Grotowski, refugiado político e peregrino apátrida.

No campo do teatro, podemos ver o trabalho de Grotowski (como ele próprio costumava afirmar) como uma continuação de Stanislavski, e nos círculos poloneses, também como uma continuação do Teatr Reduta, de Osterwa e Limanowski ${ }^{6}$. No campo mais obscuro da tradição artística, filosófica, cultural e espiritual, Grotowski pode ser melhor compreendido por sua relaçáo com o Romantismo e, especialmente com Mickiewicz, de quem o Teatro Laboratório tirou o lema: ritos cheios de bruxaria e blasfêmia (Mickiewicz, 1998, p. 164-165).

Grotowski encenou o drama Forefathers'Eve (Os Antepassados) de Mickiewicz, em 1961, e outra grande obra romântica de Juliusz Słowacki, Kordian, em 1962. Słowacki também foi autor da adaptação polonesa de Calderón, O Principe Constante, que Grotowski levou ao palco em 1965, e do poema dramático Samuel Zborowski, que deu início ao longo processo de incubação do que finalmente seria o Apocalypsis cum figuris, no final dos anos 1960. Com Akropolis, baseado na peça do dramaturgo neo-romântico Stanisław Wyspiański, o Teatro Laboratório parece uma fase moderna do Romantismo polonês, uma afirmação feita muito raramente por estudiosos de língua inglesa (Kuharski, ${ }^{1999)}$, e, curiosamente, não suficientemente pela crítica literária polonesa ${ }^{7}$. Se a razão para essa omissão por parte do estudioso ocidental é a falta de familiaridade com as nuanças do fenômeno romântico polonês, é, sobretudo, a canonização do período, pela crítica literária polonesa, que deixa pouco espaço para os especialistas em teatro polonês.

Uma análise abrangente da conexão entre Grotowski e Mickiewicz demandaria um outro artigo, que vou deixar para ser escrito por outros. Uma grande quantidade da literatura crítica polonesa dedicada a Mickiewicz requer uma séria análise, levando-se em consideração a especificidade e a complexidade do ambiente cultural polonês, no qual o orgulho nacional e a agenda política são fatores 
difíceis de discernir. Além disso, as obras de Mickiewicz e Grotowski, em seus períodos de maturidade, continuam sendo extremamente controversas na Polônia, o que também exigiria uma análise cuida$\operatorname{dosa}^{8}$. Neste artigo, eu me concentro no que os paralelos entre suas respectivas obras revelam sobre o tema de seus intrincados legados, obscurecidos por uma suposta, percebida ou admitida aproximaçáo com o misticismo, e preocupados com o seu afastamento (mesmo que progressivo) da arte convencional em direção ao trabalho do homem interior. Ambos peregrinos na arte e na vida, Mickiewicz e Grotowski chamam a atenção para suas vidas como atos performativos e para a busca incessante de um propósito para o qual a arte serviu apenas como veículo - tudo no espírito do Romantismo polonês. A especialista americana em literatura eslava Halina Filipowicz, coloca as palestras (e outros atos de performance oral) de ambos os professores na categoria da performance arte' ${ }^{9}$. Como, talvez, deveriam ser vistas todas as outras atividades desses dois peregrinos.

O patrimônio artístico é sempre resultado de uma combinação de circunstâncias culturais e escolha individual. O Romantismo polonês - que Grotowski abraçou tanto como contexto cultural quanto como escolha consciente - pode ajudar a compreender o fio condutor do seu trabalho, que se originou em Stanislavski e Meyerhold na cena teatral e amadureceu como uma performance sem público do homem interior.

Vou apresentar uma necessária visão geral do Romantismo polonês, concentrando-me em Mickiewicz, seguida por uma análise da famosa Palestra XVI que Mickiewicz deu em 1843, na qual falou sobre a capacidade do Drama Romântico eslavo de dar nova vida ao teatro europeu. Especificamente, Mickiewicz mencionou os contadores de histórias folclóricas eslavos e seu uso dos mitos, elementos sobrenaturais e técnicas de performance, remontando a Homero como a direção que o teatro do futuro deveria seguir, e deixou um desafio e apelo às geraçôes futuras de poloneses para que criassem um teatro digno da sua cultura popular e literatura romântica. Um dos discursos mais importantes da história do teatro polonês, a palestra foi transcrita de anotaçôes não autorizadas - como Grotowski, Mickiewicz improvisava suas palestras ${ }^{10}-\mathrm{e}$, mais tarde, traduzida do francês para o polonês e publicada após sua morte. A palestra inspirou muitos artistas poloneses de teatro do século XX. Além de Grotowski, estão: Stanisław Wyspiański, Juliusz Osterwa, 
Miron Białoszewski, Leon Schiller, Tadeusz Kantor e Wlodzimierz Staniewski (do Centro de Práticas Teatrais, Gardzienice), e todos eles ou rejeitaram a instituição do teatro ou expandiram radicalmente seus limites (Osiński, 1998, p. 219).

Talvez seja a essa linha de tradição da cultura popular, abraçada pelos místicos do Romantismo, que Anatoly Vasiliev se referiu como um conhecimento secreto, algo que apenas o espirito eslavo pode saber, quando comentou sobre o que Grotowski havia encontrado em Stanislavski ${ }^{11}$. Eu irei desafiar meu espírito eslavo para contar o que ele sabe sobre a conexão entre Mickiewicz e Grotowski.

\section{Contexto Histórico}

Em Paris, Mickiewicz vivia a vida de um refugiado, lamentando o colapso do estado polonês e ansiando por sua restauração ${ }^{12}$. Poeta, intelectual e agora professor, ele buscava e desejava mobilizar possíveis aliados políticos dentre os círculos liberais europeus, que já sentiam os ventos próximos dos levantes da Primavera das Naçóes, em 1848.

Com sua história heroica e trágica, a Polônia se destaca na Europa, com uma singularidade profundamente refletida na atitude e na mentalidade dos poloneses. O orgulho inspirado por seis séculos de vastidão territorial e poder político e militar, que perduraram até o final do século XVII, deve compensar a deterioração, a vitimização da Polônia por países vizinhos, e seu consequente desaparecimento do mapa europeu nos 150 anos seguintes. Aquele período foi fortemente marcado por revoltas e guerras travadas por poloneses vestindo uniformes de diferentes exércitos estrangeiros, frequentemente lutando uns contra os outros, mas sempre pelo mesmo objetivo, que era a restauração do estado. A partir de 1772 (e até 1918) a nação polonesa manteve sua identidade através da resistência aos esforços dos invasores em aniquilar a língua e a cultura polonesas. Apesar das políticas de repressáo levadas a cabo com diferentes intensidades no território dividido da Polônia (ou talvez por causa delas), a literatura polonesa floresceu, criando o que desde então tem sido reconhecido como sua melhor poesia lírica e épica, e drama poético. Quatro dos românticos mais famosos entre os maiores poetas poloneses da época, Mickiewicz, Juliusz Słowacki (1809-1849), Cyprian Norwid (1821-1883) e Zygmunt Krasiński (1812-1859), passaram grande parte de suas vidas em Paris, onde eles morreram como refugiados ${ }^{13}$. 
Como um movimento intelectual bastante amorfo, o Romantismo na Europa Ocidental abraçou o individualismo, o subjetivismo e o espiritualismo, com os quais rebateu as visóes de mundo da Idade da Razão. Ele foi uma rebelião artística e política contra alguns dos aspectos do Iluminismo, uma busca por inspiração nos mitos e rituais pagãos e uma legitimação da tradição oral inferior através da arte elevada. Essa característica bastante igualitária do Romantismo reverberou nas revoltas da Primavera das Naçóes que mobilizaram um amplo espectro da sociedade com variadas agendas políticas e/ ou sociais em diferentes partes da Europa e dos Estados Unidos. Sem um objetivo similar, o único fator comum no movimento romântico parece ter sido o nascimento do sujeito, isto é, o surgimento do conceito moderno de nação e a mudança para um sentido de lealdade e obrigação mais nacional do que local (feudalmente definido). Se os pensadores do Iluminismo iniciaram um discurso sobre questóes sociais, os românticos o desafiaram ao nível da representação, ao aceitarem o sentimento enterrado no inconsciente coletivo e sua expressão entre os grupos sociais que operam dentro da tradição oral (habitantes de pequenos povoados e camponeses). Entretanto, a atitude rebelde e revolucionária que liquidou os modelos científicos e ordenados do progresso humano e social era, em sua essência, profundamente holística, incluindo a parte subjetiva e intersubjetiva da percepção humana do mundo. Nas mãos de Grotowski, em especial, os trabalhos dos românticos parecem ser uma busca por uma totalidade que a humanidade negligenciou através da negação de seu inconsciente enterrado nas suas raízes culturais primitivas.

A corrente polonesa do Romantismo misturava o patriotismo, o liberalismo, o catolicismo, o paganismo e o misticismo com a missão política concreta de preservar a identidade nacional e, eventualmente, restaurar o Estado. Ela operava no espírito pampoético, uma visão de mundo que valorizava a poesia mais do que as outras artes, mais até do que a religião. $O$ poeta romântico polonês assumiu o status de padre e vidente - um guru - que através de sua genialidade verbal (tanto oral quanto escrita) era capaz de despertar os coraçóes dos poloneses, e levá-los primeiro à grandiosidade espiritual e depois à independência nacional. $\mathrm{Na}$ medida em que seus objetivos eram políticos, com interesses nacionais em jogo, Mickiewicz pretendia mobilizar a alma individual. Ele acreditava que o trabalho de um 
indivíduo sobre si mesmo servia à causa da nação polonesa, um passo em direção ao resgate de sua autonomia.

O Romantismo polonês também sustentou uma crença messiânica no papel da Polônia nos assuntos do mundo. Um mártir escolhido por Deus, um Cristo para todas as naçóes, a perda da soberania da Polônia serviu como o sacrifício necessário à salvação do mundo. É difícil dizer o quanto essa atitude ajudou a preservar a esperança das geraçôes de poloneses que viveram sob a repressáo de governos estrangeiros; no entanto, a partir do século XIX, até os dias de hoje, o patriotismo polonês mantém uma ambição quase irracional. Podemos encontrar traços de messianismo em algumas leituras do surgimento do movimento Solidariedade em 1980, a eleição do Papa polonês, a lei marcial de 1981, a abolição pacífica do governo pró-soviético em 1989 ou, mais recentemente, na adesão da Polônia à coalizão anti-Iraque liderada pelos EUA e formada por quatro países. Se, para o mundo, a Polônia parecia improvável entre os Estados Unidos, a Grã-Bretanha e a Austrália, isso se deve à falta de familiaridade do mundo com o aspecto messiânico do patriotismo polonês e da ambiçáo política moldada pela sua literatura romântica, na qual Adam Mickiewicz é uma figura chave. Em suma, a Polônia e os poloneses nunca deixam de se identificar com heróis românticos ${ }^{14}$.

É difícil superestimar a influência do movimento romântico nas atitudes e na cultura da Polônia. Małgorzata Dziewulska afirma que cada geraçáo encontra nele uma fonte de fascínio revolucionário:

Somente em sumários de livros [o Romantismo] é listado entre outros períodos literários como mais um capítulo. $\mathrm{Na}$ realidade, o Romantismo domina todos os outros períodos. Sua classificação vem em parte do papel que ele vem desempenhando na história. Mas, principalmente porque nenhum outro trabalho literário em língua polonesa atingiu tal magnitude artística, riqueza de pensamento e ousadia poética. Ele constitui o auge do espírito da linguagem. Tudo o que há de importante na poesia e no drama teve de se elevar em relação à sua fonte, tudo o que há de atormentado e inquieto no teatro teve de encontrar um caminho em sua direção [ao Romantismo] (Dziewulska, 2005, p. 49).

Ao analisar a influência do movimento romântico no teatro polonês, o colaborador de Grotowski, Ludwik Flaszen, o enalteceu como uma fonte de inspiração e desafio a nível individual, que originou visões ousadas e até mesmo obsessóes, exigiu reaçóes artísticas destemidas, ao mesmo tempo em que encorajou a inquietação criati- 
va. Ele subestimou propositadamente o papel do Romantismo como monumento cultural e patrimônio nacional. Ao invés disso, afirmou que muita coisa de valor surgiu, no palco pós-romântico polonês, a partir do espírito de rebelião, escárnio, ironia, raiva, blasfêmia e transgressão - justamente as características da consciência romântica. Até mesmo os modernistas, incluindo Witkiewicz e Gombrowicz, estavam reagindo de acordo com a revolta romântica. Ao contrário da maior parte da literatura polonesa convencional, Flaszen vê o Romantismo como um fenômeno profundamente contemporâneo, precisamente porque ele acolhe a inquietação. De acordo com Flaszen, toda a vanguarda polonesa tinha bases profundamente românticas, mesmo quando se colocava contra o Romantismo, e acrescenta: "[...] inventar o Romantismo como uma nobre tradição é traição; montar um altar para um herege, civilizar um 'excêntrico desleixado"” (Dziewulska, 2005, p. 49).

Em uma conferência dedicada a Grotowski em Miláo, na Itália, em 1979, o crítico literário progressista Konstanty Puzyna referiuse ao drama romântico como um ritual de iniciaçáo: "[...] neste entendimento, a iniciação significa sujeitar alguém às tentativas de intensificação do choque cognitivo, através do qual se cruza as barreiras e entra-se em outra dimensão na qual a verdade é percebida diretamente com todo o ser" (Dziewulska, 2005, p. 51). Em sua fala na conferência, Grotowski enfatizou o espírito do Romantismo presente em uma ação individual ousada: "[...] o que é uma atitude romântica? Na Polônia ela é a resposta de uma pessoa à vida e à história" (Dziewulska, 2005, p. 51).

Vemos que as respostas do próprio Grotowski ao teatro, ao excedê-lo ou expandi-lo no Parateatro e, posteriormente, na Arte como veículo, corroboram esse ponto de vista. E também suas respostas aos próprios românticos, com montagens não-ortodoxas de seus poemas dramáticos não-encenáveis, sem dúvida o colocaram entre aqueles de atitude romântica, que identificam e seguem sua própria necessidade, e confrontam o mundo com ela e através dela. Assim, o caminho de Grotowski em direção ao teatro interior se alinha à essência do espírito romântico. Seu pessimismo em relação à humanidade foi equilibrado (ou anulado) pela esperança persistente identificada no potencial de cada ser humano como um homem total, atitude essa que ele compartilhou com Mickiewicz, que criou o termo em polonês (Grotowski, 1980). 
A impressionante obra literária ${ }^{15}$ de Mickiewicz inclui trabalhos de seu relativamente breve periodo poético (1821-1835), como os dramas poéticos Dziady cz. II e IV, Dziady cz. III (Forefathers'Eve - "Os Antepassados" - Parte II e Parte IV, Forefathers'Eve - Os Antepassados - Parte III), que compreendem uma parte significativa da identidade cultural polonesa nacional e individual. Devido à complexidade dessas obras e à abundância da literatura secundária produzida sobre elas, eu irei me concentrar apenas em alguns aspectos que se relacionam com Grotowski.

O ciclo Forefathers'Eve (Os Antepassados), que se pode descrever, usando um conjunto completo de traços românticos, como patriótico, político, pampoético, messiânico e blasfemo, foi inspirado em um dos mais antigos ritos pagãos, Dziady (Os Antepassados), de onde Mickiewicz tirou seu título. $\mathrm{O}$ rito, que inclui levar comida e bebida a cemitérios para compartilhá-los com os espíritos dos antepassados, havia sido absorvido, difundido e substituído pela Igreja Católica pelo Dia de Todos os Santos; no entanto, ele continua sendo amplamente praticado em sua forma pagá entre os camponeses até hoje (Kolankiewicz, 1999, p. 31). O tratamento que Mickiewicz deu ao rito nas Partes II e IV de "Os Antepassados" reconecta a literatura dramática ao elemento sobrenatural existente na tradiçáo oral, e, assim, renova a busca do teatro por suas origens ontológicas nos "ritos cheios de feitiçaria e blasfêmia":

[...] os Banquetes das Almas dos Antepassados, aquelas reuniôes em círculos, charnecas, ou cavernas à meia noite - ritos cheios de feitiçaria e blasfêmia -, mantêm nosso povo na ignorância; daí todas as superstiçôes, todas as histórias estranhas sobre fantasmas, apariçóes e magia (Mickiewicz, 1998, p. 164-165).

O Teatro Laboratório buscou aquilo que Ludwik Flaszen chama de "psique arcaica", a totalidade do homem em harmonia com o mundo natural e sobrenatural: "[...] nosso trabalho é uma tentativa de ressuscitar as características arcaicas do teatro. Não somos modernos, pelo contrário, somos absolutamente tradicionais" (Dziewulska, 2005, p. 51). Apesar de sua importância intelectual, o teatro, para Flaszen, permanece relacionado à magia:

[...] a relação entre teatro e magia é mais do que meramente genética. Ela náo é dependente dos conteúdos expressos no palco. Esses conteúdos podem ser altamente cerebrais, críticos, e esclarecidos; no entanto, no teatro, eles viverão como encantamentos mágicos. [...] Isso é assim, pois o tea- 
tro é o incitamento dos demônios, mesmo que ele negue a si mesmo sua identidade original e se fantasie com perucas empoadas de acadêmicos e com disciplina da mente (Flaszen, 1974, p. 108).

A rebelião romântica de Flaszen "contra o domínio do racional" lembra a de Konrad, um dos personagens da Parte III de Os Antepassados de Mickiewicz. Esse célebre poema dramático contém $A$ Grande Improvisação (Mickiewicz, 1955), um monólogo que exemplifica a mentalidade romântica polonesa em toda sua glória pampoética ${ }^{16}$. Já que esse célebre texto influenciou profundamente a atitude do teatro polonês do século XX, discutirei suas principais características.

Preso por seu envolvimento com uma organização patriótica clandestina, o herói dramático de Mickiewicz, Konrad, transformase de poeta do amor romântico em um poeta-combatente pela causa nacional. Sozinho em sua cela, ele não mais deseja uma audiência ou mesmo um outro meio que não a sua própria alma, e realiza sua improvisação poética diretamente para Deus. A linguagem é mais uma superfície que recobre do que algo que revela os rios de sentimentos que correm em sua alma:

Sentimentos fluem na minha alma, se acendem, faíscam,

Como sangue em seus leitos de rios invisíveis;

Veja o sangue em minha face,

E leia todos os sentimentos em minhas canções.

Com Deus como única testemunha, Konrad declara seu trabalho interior como o único lugar e meio para sua performance. Sua prisão agora representa a reclusão artística na qual a linguagem permanece, como um traço da grande obra poética da alma. Ele continua com uma declaraçáo sobre a impossibilidade de representaçáo do gênio artístico. A profundidade da arte está no processo interno do artista e sua recepção só seria possível através de uma relação não mediada, como aquela entre o Homem e a Natureza, e entre o Homem e Deus.

Digno de Deus, digno da natureza é este canto,

Esta canção, esta grandeza, esta canção-criação;

Tal canção é audácia, tal canção é capacidade,

Tal canção é imortalidade.

Essa autoadmiração aparentemente arrogante do poeta tem um caráter prometeico mais do que narcisista. Sua causa é a causa de toda a nação:

O meu amor não é por uma pessoa apenas,

como uma abelha em um botão de rosa, ele não recai, sobre uma família, ou uma época apenas. 
Eu amo toda uma nação! Eu abraço

Todas as suas geraçóes passadas e futuras,

E eu as aperto junto ao peito,

Como um amigo, um amante, um marido, um pai;

Eu quero aumentá-la, fazê-la feliz,

Quero que o mundo a admire

Essa explosão pampoética é logo seguida por uma blasfema divinizaçáo do sentimento poético, e pelo pedido do poeta por ter um poder totalitário sobre as almas, uma maneira de amalgamar à causa nacional um imperativo religioso:

Eu nasci um criador;

Meus poderes vieram do mesmo lugar que os seus;

e você não pediu por eles da mesma forma.

O que você obtém dessa maneira, não tem medo de perder.

Eu também não.

O poder que eu tenho sobre a natureza,

Gostaria de usar sobre as almas,

Da mesma forma que eu domino os pássaros e as estrelas,

Gostaria de governar as pessoas.

Náo com armas - as armas repelem as armas

Não com cançôes - elas crescem muito lentamente,

Não com o conhecimento - ele molda com excessiva rapidez,

Não com milagres - eles são pretensiosos demais.

Quero governar com um sentimento, aquele que tenho em mim;

Governar como Você o faz, a todos, para sempre, de forma misteriosa:

O que eu quero, deixe-os adivinhar,

Se eles o conseguirem, alcançarão a felicidade,

Se eles o contestarem, sofrerăo e perecerão.

Deixe que eles sejam para mim como pensamentos e palavras,

Dos quais se eu quiser posso tecer uma canção,

Ouvi dizer que Você governa dessa forma!

Você sabe que eu nunca estraguei um pensamento, nunca desperdicei uma palavra,

Se, sobre as almas, Você me conceder igual poder, como uma canção, eu poderia criar a minha nação,

Uma maravilha maior que a Sua;

Eu cantaria uma canção feliz!

É o Seu poder que eu agora exijo,

Da mesma forma como Você governa as almas, eu quero governá-las.

Mesmo que blasfema, essa demanda por poder divino sobre as almas a ser dado apenas ao sentimento do poeta pode ser lida como 
uma contestação dos meios (armas, música, conhecimento, milagres), ou seja, forma e signo. Contudo, aquilo que se manifesta como um anseio por uma recepção não mediada do sentimento artístico, que desafia a maneira como Deus usa sua autoridade (por exemplo, através de "milagres pretensiosos"), também traz outra mensagem desafiadora. A ousada autocomparaçáo do poeta com Deus ("Eu nasci um criador;/ Meus poderes vieram do mesmo lugar que os seus") ecoa o tema gnóstico do poder esotérico do Homem adquirido não pela educação ou análise empírica, mas pela autorrevelação - um tema que eu considero de suma importância em Grotowski. É importante perceber que quando Konrad finalmente blasfema de forma absolutamente romântica ao chamar Deus de "sabedoria", ele o faz em nome do Homem revelado. Ele ou ela torna-se completo(a), com os sentimentos e o mundo interior subjetivo tendo prioridade sobre a razão objetiva, isto é, torna-se "total" ou "um ser humano completo":

Você está em silêncio!

Agora eu $\mathrm{O}$ reconheço, e como Tu governas,

Ele mentiu, quem quer que tenha te chamado de amor,

Pois tu és a sabedoria, a sabedoria e nada mais.

Para conhecer o Teu caminho deve-se usar a mente e não o coração,

Com a mente, não com o coração, pode-se aprender a tua arma,

Somente aquele que garimpou livros,

Metal, números, cadáveres,

Somente ele poderá roubar um pouco do Teu poder;

Veneno, explosivos, vapor,

Faíscas, fumaça, explosões,

Truques de advogados, astúcia.

Para a mente, Tu entregastes este mundo.

Konrad justapóe ao mundo governado somente pela razão, com sua formulação dominantemente empirista, materialista e científica, o amor parental que ele sente em nome de sua nação:

Agora com minha pátria minha alma está fundida,

E sua alma eu engoli com meu corpo,

Eu e minha pátria somos um.

Milhôes é o meu nome, eu sofro por milhôes,

Olho para meu pobre país como se olhasse para um filho

Após a execução de seu pai;

Sinto a dor de minha nação,

Como uma mãe sente a dor de um feto em seu peito.

Ao colocar em um palco virtual um herói dramático que é um poeta-profeta, e que, por meio de sua performance oral autoglorificante e Pampoética, usurpa um papel de dimensão prometeica, 
Mickiewicz zomba de sua própria ambição. O ciclo Os Antepassados mistura figuras históricas reais com personagens e situaçóes fictícias, como se estivesse insistindo que a obra de arte é uma ação em confronto direto com o aqui e agora. Como vou mostrar mais à frente, pode-se encontrar uma visão similar na maneira de Grotowski encenar Apocalypsis cum figuris. O ápice da improvisação de Konrad exemplifica essa abordagem: o herói amaldiçoa Deus com a palavra política e emocionalmente carregada "czar":

Você está em silêncio. Você confia em Sua força,

Mas saiba que o sentimento irá queimar o que a mente não for capaz de desvendar!

Você vê este fogo? Você vê meu coração?

Eu mantenho, comprimo, cultivo esta chama,

Eu a carrego na armadura da minha vontade,

Como uma bala em um canhão devastador!

Fale, ou eu irei atirar contra a Tua natureza,

E se eu não transformá-la em escombros,

Irei sacudir os alicerces do Teu reino,

Pois irei lançar uma palavra na Tua criação,

E essa palavra será repetida por geraçóes,

Que Tu não és meu Pai, mas...

Um Czar!

Em resumo, um herói solitário, cujo trabalho e sacrifício não foram totalmente compreendidos, dedica o seu gênio à luta pela sobrevivência de sua naçáo. Sonhando com a liderança espiritual, ele se atreve a brigar com Deus - ou talvez com uma imagem culturalmente contextualizada e politizada de Deus. Pathos, arrogância, idealismo, autossacrifício pela causa maior, desprezo pelo pragmatismo, e uma atitude pan-artística encontraram, de um modo ou de outro, continuidade ou resposta na vanguarda e também no teatro polonês convencional das décadas de 1960 e $1970^{17}$. Uma resposta quase direta a essa cena aparece em $O$ Principe Constante, de Grotowski, no qual o herói idealista sacrifica a si mesmo por uma causa maior, religiosa no texto de Słowacki (e no de Calderon), mas, mais geral, se não implicitamente política, na montagem de Grotowski. Curiosamente, nesse projeto, Grotowski conseguiu (mesmo que inconscientemente) jogar com o tema do amor romântico versus o amor pela causa maior. Em seu retrato do Príncipe, Ryszard Cieślak relembra a memória de seu primeiro amor de juventude enquanto fala os monólogos de um mártir ${ }^{18}$. 
Os leitores que, seguindo Mickiewicz através de seu Konrad, começam a fazer conexôes com o poeta francês louco do século XX deveriam sentir-se (cautelosamente) encorajados. Sem dúvida, $A$ Grande Improvisação, particularmente quando combinada com a palestra de Mickiewicz sobre teatro, poderia impulsionar Grotowski a tornar o teatro artaudiano possível, mesmo sem nunca ter lido Artaud.

Ainda mais importante, no entanto, particularmente no que diz respeito à indução de um complexo processo interior na testemunha através do processo interior do performer, e à ideia radical do processo interior como uma obra de arte, $A$ Grande Improvisação entra em ressonância com o trabalho desenvolvido no Workcenter. Mas, antes de desenvolver essa ideia, devo ao leitor uma introdução a um dos textos mais influentes na história do teatro moderno polonês: a palestra de Mickiewicz sobre teatro.

\section{Palestra XVI}

Mickiewicz focou seu curso no Collège de France na poesia eslava e, principalmente, na poesia patriótica polonesa. Sua palestra de final de semestre, entretanto, foi dedicada ao teatro, que, para ele, tem o potencial de transformar a poesia em ação:

[...] o drama é a realização mais elevada da poesia. $\mathrm{O}$ drama quase sempre anuncia o fim de uma época e o início de outra. [...] O drama exige que os pés estejam no chão: ele precisa de um prédio, atores, e da ajuda de outros gêneros de arte. No drama, a poesia torna-se uma ação diante dos espectadores. [...] O drama deve unir todas as forças vitais da poesia verdadeiramente nacional, e como uma instituição política da nação, deve expressar seus objetivos políticos (Mickiewicz, 1955, p. 116-117).

Mickiewicz via o teatro como uma força social e política potencial, capaz de transformar a sociedade, uma força por um lado inspirada pelas ideias do Iluminismo, mas, por outro, profundamente mística e espiritual. Através de "ações" que despertassem no espectador seu "potencial interior", esse teatro reivindicaria da igreja o papel de agente no encontro comunal catártico com Deus, bem como o seu palco: a alma humana. Na prática, Mickiewicz imaginou o teatro orientado em torno de uma mistura entre misticismo cristão e pagão.

Devemos também considerar a noção do milagroso. [...] o milagroso náo é um elemento introduzido na poesia para promover a curiosidade ou para tornar o poema mais 
atraente, mas ele é um elemento de cada obra de arte que contém em si mesma uma forma de vida. Os naturalistas dizem que toda planta, toda forma de vida orgânica, ao final de uma análise, revela um componente inexplicável, um milagre. Esse milagre contém o princípio de sua vida orgânica. $\mathrm{O}$ mesmo se aplica à poesia. Em cada poema, há uma vida orgânica inexplicável, ou um elemento de mistério, que [...] revela a si mesmo como um sopro do mundo superior, como uma memória nebulosa ou um sentido do sobrenatural [...] a presença de Deus (Mickiewicz, 1955, p. 118-119).

Esse foi um ponto de entrada, na palestra, em um território familiar não apenas para seus leitores, mas também para os leitores de Goethe, Schiller, Byron, Shelley e Keats - uma invocação da cultura popular tradicional, repleta de crenças ingênuas no sobrenatural, cheia de histórias de fantasmas, ninfas e outras apariçóes preservadas através de rituais, costumes, superstiçóes, contação de histórias, canções e dança. Mickiewicz falou sobre a noção celta de segunda visão, sobre o conceito da cultura popular germânica de visita de fantasmas, mas, sobretudo, sobre a crença eslava em espíritos, duendes e apariçôes:

Os povos eslavos acreditam acima de tudo em fantasmas (aparições, bicho-papão, duendes - nenhum desses termos traduz a palavra upiór), e até mesmo desenvolveram uma teoria filosófica sobre eles. [...] Mas, filosoficamente falando, essa crença não é nada mais do que a fé no individualismo do espírito humano, e no individualismo dos espíritos em geral; em nenhum lugar essa fé foi tão forte quanto com os eslavos. Portanto, nenhuma teoria panteísta será capaz de criar raízes lá - o instinto nacional irá afastá-la. Nós sabemos pela história e pela mitologia o quanto o culto aos espíritos era importante na religião eslava; até mesmo hoje em dia as pessoas convocam os espíritos dos mortos, e dentre todos os feriados eslavos o maior e mais festivo é o feriado dos Antepassados. Se, entre os eslavos, podem-se encontrar indivíduos que através de seus contatos com a classe esclarecida negaram suas práticas religiosas ou esqueceram completamente a Bíblia, não se pode encontrar qualquer um que tenha perdido a fé na existência de espíritos após a morte (Mickiewicz, 1955, p. 119-120).

Mickiewicz claramente promoveu a cultura da magia sobre a cultura da razão. Mas ele também favoreceu a cultura de admiração e respeito ao invés da nihil admirari (nada para se admirar), em voga entre aqueles de uma posição social e intelectual mais alta. Aqui, Mickiewicz fez uma homenagem à capacidade dos camponeses da Polônia de admirar, estranhar e maravilhar - forças motrizes por 
trás da contação de histórias. Já que nos contos populares o elemento sobrenatural é representado através da palavra falada, a cultura ingênua foi capaz de desenvolver um sentimento e um apreço pela linguagem e performance oral. Para os camponeses poloneses, segundo ele, as palavras são mais importantes do que a representação visual. Contudo, ele admitiu a importância da performance oral em sua totalidade, incluindo o elemento visual. Se as ambientaçóes naturais pobres desses eventos de contação de histórias não eram, para Mickiewicz, um modelo que devia ser seguido pelo teatro, elas estavam mais próximas, em espírito, da literatura dramática romântica do que do palco tradicional, que o poeta via como convencional, elitista e impotente:

Não devemos esperar por qualquer encenação de um drama eslavo num futuro próximo. Nenhum teatro poderia montá-lo. [...] Em geral, a arquitetura dos teatros fica aquém dos movimentos literários. Na França, apenas o Cirque Olympique seria adequado para um espetáculo mais sério (Mickiewicz, 1955, p. 122).

Ele então criticou a dependência a cenários e avanços técnicos nas montagens como um sinal do declínio do drama, e elogiou Shakespeare por encenar as suas peças "sem cenários ou máquinas" (Mickiewicz, 1955, p. 123). Podemos interpretar esse sentimento como um precursor de duas ideias que, mais tarde, tornaram-se de importância fundamental nas primeiras montagens de Grotowski: o teatro pobre e o repensar do espaço teatral.

Mickiewicz expressou suas dúvidas sobre a possibilidade de produçôes bem sucedidas de seus dramas em um futuro próximo; no entanto, encorajou poetas a não sujeitar seus trabalhos às convençôes ou a outras limitaçôes de produção. Em outras palavras, ele queria que a literatura dramática permanecesse impossível de ser montada e, portanto, independente da prática teatral. Isso não deveria de forma alguma ser visto como sentimento não-teatral, mas como um desafio corajoso à prática da encenação. Ele claramente deixou a pampoética grávida da panteatralidade futura, que surgiu na Polônia na segunda metade do século XX, como o teatro de diretor de Konrad Swinarski, Tadeusz Kantor, Andrzej Wajda, Adam Hanuszkiewicz, Kazimierz Dejmek, Jerzy Grzegorzewski, Jozef Szajna, Wlodzimierz Staniewski e Jerzy Grotowski (Grodzicki, 1979). Ao final da Palestra XVI, Mickiewicz definiu o teatro como "a mais plena realização da poesia", na qual a "poesia torna-se um ato [fazer] na direção dos espectadores", 
em que a palavra torna-se uma ação (Mickiewicz, 1955, p. 116-117). A esta formulação, Nietzsche adicionaria que para que a palavra seja uma ação nós devemos percebê-la como um clarão de luz ou como uma fogueira - náo como a causa, e nem como o potencial, mas como a própria ação sem sujeito (Nietzsche, 2000).

O Romantismo aspirava a mais do que ser encenado. Era uma época em que o dramaturgo era quem desafiava as convençóes e limitaçóes teatrais, e escrevia o discurso como ele se dava em sua imaginação, sem considerar a realidade da produção, isto é, fora da instituição cultural do teatro. Não eram apenas as limitações técnicas que impediram o teatro do século XIX de satisfazer as aspiraçóes do dramaturgo romântico, mas a falta de sincronicidade do teatro com os aspectos rebeldes da poesia dramática, ou ainda a falta de maturidade como sua própria autonomia artística. No caso de Mickiewicz, as preocupações com a montagem de sua poesia dramática na Polônia ocupada, onde seus trabalhos haviam sido banidos, foram, sem dúvida, abstratas. Os poloneses produziram a sua obra, copiando à mão poemas e discursos e lendo-os em voz alta em pequenos círculos reunidos em residências particulares; tudo isso era ilegal e a punição podia ser a prisão e os trabalhos forçados na Sibéria - um fato histórico conhecido, e um sentimento antimoscovita difícil de ignorar, mesmo na Polônia comunista pós-Segunda Guerra Mundial sob o domínio Soviético.

Desde a restauração do estado polonês, em 1918, os dramas de Mickiewicz foram levados para o palco como um tesouro nacional, porém o teatro moderno e modernista buscou material em outros lugares. Com suas montagens de Mickiewicz, Słowacki e Wyspiański, na década de 1960, Grotowski trouxe o Romantismo à moda novamente. $\mathrm{O}$ teatro que respondeu às necessidades dos textos dramáticos de Mickiewicz, o fez tratando-os como inspiração e como irmãos de armas e, assim, mais como um elemento do trabalho autônomo no palco do que como um tesouro literário que usava o palco. Em outras palavras, quando o drama romântico polonês finalmente encontrou o seu teatro, ele era um teatro de diretor e não de poeta.

A transformação que permitiu ao teatro encenar o não-encenável aconteceu longe do mainstream e fora do conceito de ator-personagem. Para que o discurso poético atingisse o fazer, como Mickiewicz desejava, ele precisava ser falado por um fazedor, um ator, um performer, buscando por seu si-mesmo. 


\section{Da Poesia à Açáo Interior}

A posição de Mickiewicz como um dos maiores poetas da história polonesa (com sua posição de herói nacional e seu gênio comparado ao de Shakespeare no mundo anglófono) apresenta um ponto obscuro e problemático, que talvez tenha se mantido velado por causa da vergonha nacional. No auge de sua carreira literária, Mickiewicz parou de escrever, ficou em silencio, e envolveu-se (perdeu-se, ou foi consumido por, como os críticos afirmam) com a Koto Sprawy Bożej (Sociedade da Matéria Divina). Liderada por um místico, Andrzej Towiański, a organização obscura, esotérica, patriótica, cristâ, com características de seita, operava principalmente entre os emigrantes poloneses em Paris. O fato de que o poeta-vidente, o bardo da nação, tenha se tornado discípulo de um guru duvidoso foi de aceitação difícil por parte de seus contemporâneos, e ainda o é para muitos poloneses de hoje ${ }^{19}$. Apenas muito recentemente os estudiosos começaram a reavaliar a queda de Mickiewicz em um culto, revelando que o pensamento, a legitimidade e a popularidade de Towiański se beneficiaram muito com o poeta, o que sugere que Towiański era, até certo ponto, um produto de Mickiewicz ${ }^{20}$. $\mathrm{Na}$ minha opiniáo, a incapacidade de perdoar Mickiewicz por trair sua musa vem da incapacidade de compreender a lógica da mente criativa radical que persiste com a ação, ignorando os limites do veículo artístico. Críticos de teatro têm a mesma dificuldade com o abandono do teatro por parte de Grotowski.

Para Mickiewicz, poesia era ação, assim como sua vida era um ato de fazer. Quando jovem, ele era ativo em uma sociedade patriótica secreta e, por causa disso, foi forçado a deixar o território polonês ocupado pela Rússia. Ele tentou retornar para participar em 1830 do levante nacional, mas foi impedido pelas autoridades na fronteira russo-prussiana. Ele morreu quando tentava organizar um exército polonês na Turquia, durante a Guerra da Crimeia, em 1885. Sua arte literária deu lugar a uma açáo e a um pensamento políticos e críticos, elementos que estiveram em primeiro plano em suas palestras no Collège de France. Ele descobriu que a causa humanista e patriótica era melhor servida por um rigoroso trabalho sobre si mesmo e, assim, direcionou suas energias a um grupo dedicado a tal projeto. Entretanto, para os críticos literários, o silêncio poético de Mickiewicz - tratado por eles também com uma dose de silêncio 
- significa sua decadência artística e pessoal, uma deficiência que durou quarenta anos de sua vida madura.

Embora "[...] no Romantismo polonês o tema do existencialismo tenha se tornado irrecuperavelmente turvo, embebido pelo tema da pátria" (Janion; Zmigrodzka, 2004, p. 9), Mickiewicz esteve particularmente envolvido com as questôes da existência na última fase de sua vida. Ele o fez como pensador, orador e como membro da Sociedade de Towiański. Seu curso sobre literatura eslava no Collège de France concentrou-se no "[...] homem compreendido como texto, que precisa ser estudado para revelar as verdades importantes que contém" (Hoffman-Piotrowska, 2004, p. 75). Na sua palestra sobre o teatro, no Collège, Mickiewicz buscou essas verdades no milagroso, contido na contação de histórias populares e no mundo da imaginação eslava baseada no paganismo. A missão da Sociedade da Matéria Divina, por outro lado, era a de transformar seus membros em "um novo tipo de homem vivendo um novo tipo de vida" (Szpotański, 1938, p. 172). Os membros da Sociedade realizavam vários tipos de exercícios contemplativos destinados a moldar e aperfeiçoar o eu interior através da crença de que a alma humana, em seu nível mais profundo, encontra-se face a face com o Absoluto e une-se a ele, recuperando a totalidade que a alma perdeu. Mickiewicz acreditava no trabalho no homem interior, e encorajava seus irmáos de armas a continuálo, apesar da disciplina e sacrifício envolvidos. Eles trabalhavam de acordo com a sua fórmula: "[...] deve-se insistir com o ferro por um longo tempo para torná-lo macio e maleável. Somente quando o ferro se torna macio ele é temperado" (Hoffman-Piotrowska, 2004, p. 105$)^{21}$. Assim, o crescimento interior dependia, para Mickiewicz, do trabalho prático destinado à "renovação espiritual e elevação à esfera da realidade e da verdade" 22 . Foi precisamente esse trabalho, que para Mickiewicz se tornou um meio mais direto para se chegar à totalidade humana, que substituiu a sua produção poética.

$\mathrm{O}$ afastamento de Mickiewicz da escrita poética para dedicar-se a falar e fazer - uma decisão que revela o dilema de muitos escritores com motivaçáo política - deve ser visto como uma busca pela palavra encarnada e pela palavra-ação que afeta o mundo e tem o poder de modificá-lo. O silêncio poético de Mickiewicz foi resultado de um novo modo de ver a ação e as palavras, cuja performance telúrica resulta em uma revelaçáo espiritual no ouvinte. Esse era o uso que fazia das palavras nas suas palestras no Collège de France. Entretanto, 
mesmo a ação verbal eficaz era secundária em relação ao fazer direto, ao trabalho no eu interior, e através dele, no mundo exterior: "[...] nas palavras há apenas um desejo; no fazer, um poder impressionante" (Mickiewicz, 1982, p. 338).

Os exercícios espirituais de Mickiewicz estavam profundamente enraizados no misticismo da Europa Ocidental, e naquele do místico medieval Mestre Eckhart (c. 1260-1327/28) em particular, o qual acreditava na possibilidade de alcançar a unidade entre a alma humana e Deus. Os ensinamentos de Eckhart usam a linguagem da tradição cristá, mas sua mensagem parece semelhante à de certas filosofias orientais. A Igreja classificou alguns de seus escritos como heréticos e foi apenas em 1980 que um processo de reabilitação gradualmente teve início. Em um de seus últimos textos, Performer, Grotowski cita Eckhart: "[...] entre o homem interior e o homem exterior há a mesma infinita diferença que existe entre o céu e a terra" ${ }^{23}$ (Grotowski, 1997, p. 377). É no homem interior que Grotowski se concentra com mais eloquência nos seus últimos anos e, ao fazê-lo, segue a tradição a qual Eckhart, Towiański e Mickiewicz pertencem.

\section{O Homem Interior, o Homem Exterior e o Significado}

$\mathrm{Na}$ complexidade na qual as palavras e as açóes se relacionam, elas estáo separadas por uma lacuna lógica entre "[...] o conhecimento fatual e o conhecimento por meio de signos" (Ricoeur, 1973, p. 104), como o filósofo Paul Ricoeur explica em sua análise das açóes significativas. $\mathrm{O}$ conteúdo interno da experiência das açóes não pode ser contado em sua totalidade em função dessa incompatibilidade. Mestre Eckhart diz: "[...] a experiência mística é indizível por natureza e quando queremos falar sobre ela, nosso discurso se transforma em um murmúrio inarticulado" (Hoffman-Piotrowska, 2004, p. 167). As palavras que deveriam representar um fato interno profundo tornam-se signos insuficientes.

Essa lacuna entre o fatual e o simbólico também existe entre a obra de arte e o discurso artístico, no qual a obra de arte é um fato e um símbolo completo em si mesmo, e o discurso, o trabalho com a representação simbólica - um esforço muito bem definido por Julia Kristeva como "o ofegar da linguagem perseguindo a si própria". Wittgenstein define essa distinção como aquela entre dizer e mostrar, e a discute em seu Tratado Lógico-Filosófico. Muitas vezes lido como 
místico, o Tratado é um trabalho de lógica que luta para definir o que pode e o que náo pode ser dito: "[...] sobre aquilo de que não se pode falar devemos calar" (Wittgenstein, 2001, p. 89). No entanto, esse calar já contém o não dito, pois "[...] se apenas você não tenta dizer o indizível nada é perdido. Mas o indizível estará - indizivelmente - contido no que foi dito" (Monk, 1990, p. 151). O silêncio poético de Mickiewicz e a preferência de Grotowski pela linguagem objetiva e técnica podem ser um ato de preservaçáo, no trabalho, do indizível, que pode ser revelado sob certas condiçóes. $\mathrm{Na}$ realidade, a dificuldade de Wittgenstein em transmitir o significado de seu Tratado até mesmo para seus colegas lógicos demonstra que tanto o que pode ser dito com palavras quanto o que pode ser revelado pelo inexprimível estão sujeitos à interpretação subjetiva, e o sucesso desta depende de uma compatibilidade profunda entre os envolvidos nessa troca. Como Wittgenstein diz no prefácio, o Tratado visa a nada mais do que dar prazer a "[...] alguém que já pensou nas coisas que ele contém” (Wittgenstein, 2001, p. 3), ou seja, a alguém já iniciado ou "convertido" por uma experiência semelhante. Ele presume que para os outros o livro poderia parecer inarticulado. Em outras palavras, para Wittgenstein, o papel do livro não é tanto o de elucidar, mas o de servir como local para um encontro subjetivo, ou, talvez, até mesmo como um modo de se encontrar. Consequentemente, deve-se concluir que as palavras, assim como as açóes, não criam um processo mental, mas apenas referem-se a um. Isso também ocorre com as ações interiores, que só se revelam por meio de referências.

Um exemplo muito bom desse processo pode ser encontrado naquilo que acontece no conceito de indução de Grotowski. Ao falar sobre a recepção direta, e de modo a evitar conotaçóes misticas, Grotowski toma emprestado o termo da física, que descreve a estimulaçáo eletromagnética da corrente elétrica em um circuito fechado. De acordo com Richards, que investigou esse fenômeno no trabalho $d a$ Arte como Veículo, a ação interior do performer causa uma respostaprocesso simpática em algumas testemunhas:

[...] quando um grupo de teatro que nos visita assiste às nossas performances, e, depois, na análise alguém diz por exemplo, 'Ah, durante a performance, vocês estavam cantando. E eu não sei exatamente o que aconteceu, mas era quase como um movimento dentro de mim - dentro do meu corpo? Eu estava apenas sentado, assistindo'. Podemos ver, ah, houve indução. Mas o objetivo de nossas apresentaçôes não é o de provocar indução. Se ela fosse o nosso ob- 
jetivo, sinto que nós imediatamente perderíamos essa coisa 'interior'. Desse modo, esse é outro aspecto graças ao qual, através de um tipo especial de reflexo, podemos ver melhor a nós mesmos e a nosso trabalho, para objetivar o que estamos fazendo (Richards, 2008, p. 13-14).

Avanços recentes nas neurociências, principalmente a descoberta dos neurônios-espelho, dão confirmação científica aos relatos intuitivos do performer. $\mathrm{O}$ fato de que a recepção intersubjetiva faça parte de nossos cérebros e sistemas cognitivos (Iacoboni, 2008; Ramachandran; Blakeslee, 1998) teve e continuará tendo consequências na teoria da performance. Esse novo campo pode despertar um maior interesse acadêmico em projetos como os do Workcenter, que dependem da interação empática entre performers e testemunhas. Talvez a fenomenologia também venha a receber explicaçóes novas e mais perspicazes para termos como ser-para ou ser-com. Mickiewicz, entretanto, que rejeitava o ponto de vista científico, teria considerado essa potencial legitimidade muito irônica.

Apesar da teoria complexa e de longo alcance das neurociências, a indução, entretanto, ainda é uma maneira útil de se pensar a relação entre o performer visivelmente ativo e a testemunha aparentemente passiva - um pensamento que apenas estabelece a possibilidade de um encontro, mas náo leva a um. Esse ainda é o domínio do performer.

\section{Além dos Pontos de Convergência}

Talvez a conexão mais significativa entre Grotowski e Mickiewicz resida em seu profundo desacordo com a ordem do mundo e com a ordem interna do homem no mundo ${ }^{24}$. Essa discordância pode produzir uma açáo extrovertida visando a uma mudança radical na sociedade e/ou um movimento introvertido na direção da autoiluminação ${ }^{25}$. Esse foi certamente $\mathrm{o}$ caso com esses dois grandes artistas, que permanecem mal compreendidos com suas transformaçôes artísticas radicais. O rótulo de misticismo ajuda a descartar o que é de difícil compreensão nos seus respectivos percursos artísticos. Acusaçóes similares e confusóes acompanham Nietzsche, Heidegger, Derrida e, até mesmo, Wittgenstein, que questionaram radicalmente a sua área (e, não por acaso, para quem a linguagem tornou-se objeto de suspeita e investigaçáa). Na Polônia, essa atitude rebelde atrai, com frequência, simpatia por ser considerada romântica em espírito.

Os herdeiros de Grotowski, Richards e Biagini, podem também ser vistos como românticos poloneses, não porque eles próprios as- 
sim o dizem, mas através da herança cultural de seu professor, e por causa de seu idealismo inflexível e radical insistência em continuar trabalhando rigorosamente com o mínimo de recursos disponíveis, um orçamento realmente apertado, ou, às vezes, sem nada. Eles trabalham sobre si mesmos como atores, pensadores e pesquisadores, e compartilham seu conhecimento com comunidades artísticas de todo o mundo. Seu status, semelhante ao de exilados e modus operandi de peregrinos, lembra o do Teatro Laboratório, ou o dos cantores Bauls de Bengala, ou o Reduta, de Osterwa e Limanowski, e continua a ser algo único no mundo do teatro hoje. Quando penso no trabalho deles, as palavras de outro grande poeta romântico polonês, Cyprian Norwid, me vêm à mente: "[...] a beleza serve para atrair alguém/ a trabalhar e trabalhar - para ressuscitar dos mortos" (Norwid, 1973, p. 164). Esse lema náo chega a ser cativante (no entanto, ele soa muito bem em polonês), mas de alguma forma profunda ele reflete os temas chave da Arte como Veiculo, na qual a arte da performance leva ao ofício de estar vivo.

Algo importante a lembrar ao pensarmos sobre o inter/trans/ culturalismo de Grotowski é que a sua busca transcultural pela plenitude humana não surgiu da generalização e globalização, da busca por fatores comuns e reconhecíveis, mas sim da destruição da casca cultural e da exposição do impulso por trás do fenômeno cultural. $\mathrm{O}$ crítico polonês Zbigniew Majchrowski fala disso da seguinte maneira:

Grotowski teve de sentir-se perturbado com a homogeneização da cultura (uma teia uniforme de MTV-Music Television), mas também com todos os tipos de ostracismo cultural baseados em raça, etnia, religião e nacionalidade. Em outras palavras: ou a equalização e perda da identidade, ou a diferenciação,e agressão. No entanto, essa alternativa é falsa. De acordo com Grotowski, há uma terceira possibilidade: devemos encontrar o fator comum anterior à divisão, [...] encontrar o momento que antecede a diferença (Majchrowski, 2003, p. 475).

Essa diferença situa o trabalho interior do homem em uma moldura cultural e social, mais do que como o trabalho de um indivíduo que pode se relacionar através do reconhecimento de si mesmo no outro, usando, talvez, a forma, mas sem ter a leitura do código cultural. Grotowski não rejeita, mas conscientemente escolhe ignorar a divisão e, com ela, a estrutura de significado que ela utiliza; essa é a razão pela qual seria mais apropriado chamar sua abordagem de pré-cultural ${ }^{26}$. 
Da mesma forma, parece-me que seria errado considerar Grotowski como um católico rebelde ou situar seu trabalho interior nos moldes da religiáo. O que é santo no teatro de Grotowski contesta a narrativa cristã e torna-se humano em Apocalypsis cum figuris. Santo é prioritariamente o ator que desvela a totalidade do humano em si mesmo. O que pode ser visto como mistico é o uso desmistificado de elementos de cerimônias tradicionais. Na Downstairs Action (19881992) do Workcenter, os realizadores citaram e se apropriaram de várias práticas (liturgia católica, rituais vodu) para jogar com elas como ferramentas performativas, criando assim algo litúrgico, mas vazio de conteúdo religioso. A forma serviu à objetividade do ritual e trouxe um aspecto de iniciação a cada vez que a obra foi realizada. Sua eficiência foi admirada tanto por padres católicos quanto vudus. Um padre e professor de teologia, Roger F. Repohl, considerou sua experiência de assistir a uma performance filmada de Downstairs Action (Gregory, 1989), semelhante à sua própria condução de rituais litúrgicos, na primeira paróquia em que trabalhou em um subúrbio da classe trabalhadora de Los Angeles; algo que ele afirma ter sido perdido na Missa:

[...] todo ritual eficaz deriva seu poder de um sentido dos participantes de que ele é, de fato, uma ação, e não uma performance: de que ele não pertence realmente a eles, mas que é um tipo de molde eterno que eles às vezes atualizam (Repohl, 1994, p. 19).

O reconhecimento de Repohl da liturgia do Workcenter é um exemplo excepcional de uma reaçáo positiva de pessoas próximas à Igreja. Na realidade, por sua atitude, Repohl também merece ser chamado de um romântico polonês. Grotowski, que foi acusado de misticismo, imoralidade e de ser um simpatizante da doença do gosto ocidental com seu horror e sujeira, sofria constantes ataques das autoridades da Igreja, que tentaram persuadir o governo a fechar o seu teatro (Osiński, 2003) ${ }^{27}$. Da mesma forma, o dito (e real) misticismo e o radical liberalismo finalmente custaram a Mickiewicz sua posição como professor. Em 1844, seu empregador, uma instituição supostamente independente de ensino superior, cedeu à pressão do governo francês e da Igreja Católica. A atitude repressiva da Igreja, em ambos os casos, demonstra que o trabalho interior náo mediado transgride o território reivindicado por ela. Entretanto, se Mickiewicz trabalhou no espírito do misticismo cristâo radical, Grotowski tratou 
a religião quase da mesma forma com que tratou a cultura: buscou a força vital que ela possuía antes da divisão, ou seja, antes que a instituição definisse e codificasse a diferença. A irreverência, transgressão e ritos cheios de magia e blasfêmia, presentes em Apocalypsis e no período da Arte como veículo, se concentram na totalidade do homem do modo como ela é possível antes da divisáo idealizada pelo logocentrismo, pela política ou pela religiáo.

Mickiewicz e Grotowski compartilham uma ruptura radical com o meio que deu a cada um o seu reconhecimento artístico, o que, em ambos os casos, se assemelha a uma crise de meia-idade - ambos abandonaram seu ofício depois de treze anos de trabalho, e ambos o fizeram aos trinta e cinco anos de idade (Majchrowski, 2000, p. 44). Eu não interpretaria esses números com uma reverência mística, mas sua correspondência exata é uma boa provocação.

Uma analogia importante entre Mickiewicz e Grotowski pode ser encontrada na noção e no status sagrado do performer (sem pronome e com $P$ maiúsculo no texto de Grotowski). De acordo com Mickiewicz, o próprio poeta como poeta-orador, e poeta-personagemherói-romântico do poema dramático, junta aspectos de performer virtual e real, e de animador cultural e político que, no espírito Pampoético, é elevado a um santo. $\mathrm{O}$ ator santo de Grotowski tornase ativo como líder de eventos parateatrais apenas para dar lugar ao Performer - um ser-guerreiro idealizado e um mestre do trabalho interior. Tanto Mickiewicz quanto Grotowski confiaram o peso de seu trabalho à figura central de um atuante. Ambos eram atuantes em um sentido mais amplo. Suas respectivas presenças carismáticas, suas impressionantes habilidades de oratória, e a capacidade de improvisar durante suas aparições públicas muitas vezes resultaram em acusaçôes de charlatanismo e guruismo.

Como um poeta-herói romântico, Grotowski publicou sua missão messiânica em um livro para resgatar o teatro em sua encarnação pobre. $\mathrm{O}$ teatro pobre não era uma doutrina, mas uma reação ao teatro perdido para o glamour de fachada que ele cultivou como sua essência sublimada. O teatro pobre foi um chamado ao retorno à essência do teatro como um encontro. Mas, é a essência do pobre que leva à conexão com o Romantismo.

Em polonês, Teatro Pobre é Teatr Ubogi. A palavra escolhida não foi biedny, que significa pobreza, mas ubogi, que é uma palavra mais antiga, associada mais ao ascetismo do que à falta de dinheiro, 
ao escasso, ao enfadonho, ao inferior ou digno de pena. Esse vocabulário, em uma sociedade capitalista, faz com que pobre soe pouco atraente, impróprio. Ao invés disso, pobre significa cheio de graça, modesto, santo, despretensioso, humilde, ascético. Nenhuma dessas opçóes é precisa o suficiente para revelar o real significado de $u b o g i$, uma palavra que na cultura polonesa evoca o status social de Jesus em seu nascimento, abrigado em um celeiro.

Enquanto um dos significados de pobre está associado à peregrinação em busca da essência, outro nos remete à performance pobre da tradição oral, às profundezas da história, de volta às práticas pagãs e às múltiplas narrativas relacionadas com o sobrenatural, ao mundo anterior à divisão. Ambos os significados estão, na última fase de Grotowski em Pontedera, profundamente conectados. Naturalmente, há um paralelo em um trecho famoso em Forefathers, parte III, de Mickiewicz:

\footnotetext{
Nossa nação é como a lava,

$\mathrm{Na}$ superfície dura e fria, seca e suja

Mas até mesmo cem anos não irão extinguir seu fogo interno.

Vamos cuspir na sua superfície e descer até as suas profundezas $^{28}$.
}

Com a Igreja do lado da força de ocupação, a nação apátrida identificou seu destino em Deus como um Deus-irmão. Projetada sobre a meganarrativa do cristianismo, essa fonte pagã que Mickiewicz adotou - o mundo como uma narrativa múltipla de crença e ritual - tornou-se, no Romantismo polonês, a base da transcendência horizontal (Masłowski, 1998, p. 368), na qual Deus poderia ser procurado e encontrado no homem. Em outras palavras, a tradição romântica estendeu a mão para o cristianismo como uma irmandade de homens, na qual o homem pode encontrar Deus dentro de si próprio. Essa atitude está presente em toda a obra de Grotowski, desde seus rituais de infância na sua árvore sagrada, passando por Apocalypsis, com seu lema retirado de Teófilo de Antioquia, "Mostre-me seu Homem [człowiek] e eu te mostrarei meu Deus" (Grotowski, 2008, p. 41), até o trabalho sobre o apócrifo Evangelho de Tomé, durante o período de transmissão de seu conhecimento para Thomas Richards. 


\section{Notas}

${ }^{1}$ Fundado em Paris em 1529 para fomentar os estudos nas áreas humanas, o Collège de France sempre permaneceu independente de qualquer universidade e livre de supervisão externa. Suas classes são abertas ao público e sem a necessidade de matrículas ou taxas. Ele não oferece exames, certificados ou diplomas. Hoje em dia o seu campo de atuaçáo inclui muitas áreas humanas e científicas. Seu corpo docente - um número constante de cinquenta professores com o poder coletivo de nomear outros - inclui muitos estudiosos importantes, como Roland Barthes, Michel Foucault e Claude Lévi-Strauss. A nomeação de Grotowski foi a primeira na área do teatro, e a terceira oferecida a um polonês.

${ }^{2}$ Rutkowski e Osiński assistiram à palestra e descreveram a chegada e o comportamento de Grotowski.

${ }^{3}$ Ao ler o material biográfico, é muito fácil visualizar Grotowski-como-um-viajante. Suas andanças carregando muito pouco pela Índia, suas viagens para a Ásia Central em busca de vestígios de dervixes, sua viagem de uma década ao redor do mundo com o Teatro Laboratório, e até mesmo a sua viagem, sozinho, pegando carona, nos Estados Unidos no final da década de 1970, revelam Grotowski como um viajante. Mas, essa imagem esconde a verdadeira natureza do viajante solitário, um hóspede em seu apartamento em Wrocław, um verdadeiro transeunte com uma qualidade de sem-teto que o tornava capaz de sentir-se satisfeito onde quer que estivesse. Sua partida de Opole, semelhante a um exílio, e mudança para Wrocław foi apenas o primeiro passo de sua jornada por muitas residências, seguidas por Irvine, Califórnia e Pontedera, Itália, até o seu destino final na Índia, no Monte Arunachala, lar de Sri Ramana Maharishi, onde as cinzas de Grotowski foram espalhadas (e não apenas depositadas). As moradias de Grotowski eram pequenas e modestas. Ele frequentemente dormia em um cobertor estendido diretamente sobre o chão. Deve-se considerar a mobilidade e o minimalismo como qualidades essenciais tanto na sua arte quanto na sua vida. Os nomes dados aos marcos da trajetória de Grotowski (marcos já são parte do vocabulário de viagem) são eles próprios um testemunho: Em Busca de um Teatro Pobre, No Caminho da Cultura Ativa, Caminhando em Dirę̧ão ao Teatro das Fontes, A arte como veiculo; ou o projeto de seus discípulos, Tracing Roads Across, com seus Crossroads in Istanbul, Bridging through Mediterranean Sea, Eastern Meeting Place, etc. A mobilidade, a jornada e a continuidade são conceitos chave no trabalho de Grotowski. Ele culpava a segurança de um destino, os sistemas, conceitos e formas cristalizadas por terem traído a verdadeira criatividade na vida e na arte. Ele buscava inspiração no movimento inicial do hassidismo e do cristianismo, e em muitas outras religióes e práticas culturais ao redor do mundo, afirmando que, na sua consequente institucionalizaçáo, elas frequentemente perdiam o impulso original que as criou.

${ }^{4} \mathrm{Na}$ minha conversa com Ludwik Flaszen, o diretor literário do Teatro Laboratório que colaborou com Grotowski de 1959 até a dissolução do teatro em 1982 (oficialmente 1984), ele relembrou um evento no qual centenas de jovens acamparam numa sala do andar inferior do Teatro Laboratório por vários dias para encontrar Grotowski pessoalmente na sala de Apocalypsis: "Uma pessoa que chega deve passar por uma prova. Ela deve querer, ela deve esperar. E então estará pronta. E, então, ela chora. O que significa chorar na sala 
onde Apocalypsis foi encenada?” Ludwik Flaszen em conversa com o autor, Julho de 2004, Wrocław, Polônia.

${ }^{5}$ Grotowski tratou a sua nomeação no Collège de France com total seriedade, juntando toda sua força, que já se esvaía, por semanas antes de suas palestras. Logo após uma das últimas, ele desmaiou nos bastidores.

${ }^{6}$ Juliusz Osterwa e Mieczysław Limanowski, fundadores da Reduta [Reduto], uma companhia de teatro polonesa legendária e laboratório do período entre guerras (Osiński, 2003, 2008, 2009).

7 Zbigniew Osiński, o mais prolífico autor polonês de escritos sobre Grotowski, admite que a conexão entre Grotowski e Mickiewicz/Romantismo ainda merece mais atenção dos estudiosos (Osiński, 1998, p. 186). Leszek Kolankiewicz um célebre estudioso de Grotowski e editor dos principais textos dele durante o período parateatral, é de opinião semelhante (Kolankiewicz, 2001, p. 326). Entre os estudiosos que publicaram obras sobre o tema estão Kolankiewicz, 2001; Dziewulska, 1992, 2005; Majchrowski, 2000, p. 44. Um exemplo notável em língua inglesa é um artigo da estudiosa americana Halina Filipowicz (1999).

${ }^{8}$ Basta mencionar alguns artigos recentes nos quais Grotowski é duramente criticado (de novo!) com a mesma intensidade e argumentos similares aos usados antes de sua fama mundial: nas memórias de Jacek Dobrowolski sobre Grotowski, onde o acusa de manipular e depois trair seus colaboradores, e nas reflexóes sarcásticas de Wojciech Tomczyk sobre o antiteatro de Grotowski, que "não pegou", pois "nós somos pessoas inteligentes, e não imbecis que comprariam qualquer coisa" (Dobrowolski, 2005; Tomczyk, 2006, p. 44).

${ }^{9}$ Halina Filipowicz propóe considerar as performances orais de Mickiewicz - que incluem improvisaçôes poéticas, discursos e palestras acadêmicas - como performance arte (Filipowicz, 1999).

10 "Eu sou cristão [...] Lembrei-me das escrituras em que alguém que queria falar sobre as grandes verdades foi proibido de proferir frases prontas [...] Então eu estabeleci como regra que eu nunca iria preparar meus discursos com antecedência" (Mickiewicz, 1998, p. 177).

${ }^{11}$ Nesse breve discurso, Vasiliev lembrou-se de uma recente conferência que ministrara sobre Stanislavski e na qual perguntaram se ele não deveria sentir-se grato aos americanos por terem salvo o sistema de Stanislavski. Ele respondeu: "Agradeço muito aos americanos", e comentou que, para ele, Grotowski era quem havia salvo a maior parte do sistema de Stanislavski (Osiński, 2001, p. 259).

${ }^{12}$ Rússia, Prússia e Áustria dividiram e anexaram a Polônia em três atos políticos distintos (em 1772, 1793 e 1795), o último dos quais pôs fim ao estado polonês. Apesar das três principais tentativas de revoluçáo (em 1794, 1831 e 1863), a Polônia não havia recuperado sua soberania até o fim da Primeira Guerra Mundial, em 1918.

${ }^{13}$ Mickiewicz morreu em 1885 durante a epidemia de cólera na Turquia, onde ele estava para ajudar a montar exércitos poloneses durante a Guerra da Crimeia. Seu corpo foi enviado de volta a Paris, onde foi enterrado. Em 1890, seus restos mortais foram levados para a Polônia e enterrados entre os reis poloneses no santuário nacional da Cracóvia. 
${ }^{14}$ Como há uma vasta coleção de fontes literárias polonesas tratando desse assunto, vou deixar como referência para o leitor apenas um livro recente escrito por aquela que é provavelmente a estudiosa mais competente sobre o Romantismo e sua reverberação na cultura polonesa. Maria Janion escreve: $\mathrm{O}$ trabalho romântico e pós-romântico demonstra continuamente o aspecto doloroso do esquecimento ou da falta de reconhecimento. Ele surge de um trauma eslavo particular, do sentimento de pertencer ao grupo dos fracos e oprimidos, dos dominados e degradados; o grupo dos que são privados de uma herança oculta, os que foram injustamente esquecidos, colocados de lado, ou esmagados pelo processo chamado de progresso de civilização (Janion, 2006, p. 28).

${ }^{15}$ Dzieta [Obras Completas] de Mickiewicz contém 274 itens em vários gêneros (tratados, traduçóes, ensaios, sonetos, baladas, poemas dramáticos, poemas épicos, discursos, palestras e cartas) escritos entre 1815 e 1855, e compilados em dezessete volumes de tamanho considerável (Mickiewicz, 1998 - Traduçóes para o inglês do autor).

${ }^{16} \mathrm{O}$ termo improvisação se aplica aqui à situação dramática, na qual o herói desencadeia sua habilidade poética para expressar-se em um confronto com a testemunha silenciosa. $\mathrm{O}$ termo se refere ao estilo de performance oratória que estava em voga entre os românticos, e que Mickiewicz seguia.

${ }^{17}$ Talvez o exemplo mais famoso do teatro convencional aqui seja a produção de Kazimierz Dejmek de Forefathers'Eve (Os Antepassados) em Varsóvia, em 1968, cujo cancelamento forçado pelas autoridades, após protestos da Embaixada Russa, levou a grandes revoltas estudantis.

${ }^{18}$ Em sua fala durante o evento Hommage á Ryszard Cieślak, em 9 de dezembro de 1990, Grotowski descreveu o processo de maneira mais detalhada: o texto fala sobre torturas, sobre a dor, sobre a agonia. $\mathrm{O}$ texto fala sobre o mártir que se recusa a submeter-se às leis que ele não aceita. Dessa maneira, o texto e a sua encenação parecem servir a algo obscuro, algo implicitamente triste. No entanto, em meu trabalho com Cieślak nós nunca tocamos em nada que poderia ser chamado de obscuro. Seu papel foi inteiramente baseado em uma memória, em um momento preciso da vida de Ryszard (baseado em açóes físicas, do modo como Stanislavski as compreendia), ele baseava-se na sua memória da juventude, do momento em que ele teve a sua primeira grande experiência amorosa. Tudo estava ligado a essa experiência. Era uma invocação de um tipo de amor que acontece apenas no início da juventude, que trás em si toda a sensualidade e carnalidade, mas ao mesmo tempo há algo diferente por trás dele, algo que não é carnal, ou que é carnal de uma forma diferente, algo mais próximo de uma prece. Como se entre esses dois aspectos houvesse uma prece carnal (Grotowski, 1995, p. 23-24).

${ }^{19}$ Em seu livro, Wielkie Stulecie Polaków [O Grande Século dos Poloneses], Alina Witkowska afirma que o envolvimento de Mickiewicz com Towiański é "o maior escândalo da emigração [polonesa]" (Hoffman-Piotrowska, 2004, p. 11).

${ }^{20}$ Ewa Hoffman-Piotrowska é dessa opinião.

${ }^{21}$ Carta de Mickiewicz para Wiera Chlustin (Hoffman-Piotrowska, 2004, p. 105).

${ }^{22}$ Carta de Mickiewicz para Edmund Mainard (Hoffman-Piotrowska, 2004, p. 107). 
${ }^{23} \mathrm{O}$ texto inteiro tem influências escondidas e óbvias, e citações de Eckhart (cujo nome Grotowski nunca menciona diretamente, mas que também não esconde).

24 "O desacordo [de Grotowski] com o mundo e com a ordem interna do homem no mundo" reflete sua atitude crítica geral sobre o automatismo cultural e a máscara cultural do homem, que implicitamente ou explicitamente ecoa em cada texto que Grotowski assinou, começando pelo Em Busca de um Teatro Pobre.

${ }^{25}$ No espírito do idealismo liberal, Grotowski se envolveu diretamente como ativista na Associação da Juventude Socialista (1956-1959) durante a reforma pós-stalinista da cena política.

${ }^{26} \mathrm{O}$ argumento perspicaz de Majchrowski faz um paralelo à afirmação de Derrida de que algo afirmativo existe antes da questáo, antes da diferença.

${ }^{27}$ Ludwik Flaszen também fala sobre três formas de censura: política, religiosa e teatral (conversa com o autor, Julho de 2004, Wroclaw, Polônia).

${ }^{28}$ Tradução literal de Dziady część III, Adam Mickiewicz. Em polonês: "Nasz naród jak lawa $\mathrm{Z}$ wierzchu zimna i twarda, sucha i plugawa,/ Lecz wewnętrznego ognia sto lat nie wyziębi./ Plwajmy na tę skorupę i zstąpmy do głębi”.

\section{Referências}

DOBROWOLSKI, Jacek. Wspomnienie of Grotowskim. Res Publica Nowa, Warszawa, n. 3, p. 74-83, 2005.

DZIEWULSKA, Małgorzata. Ogniokrad. Teatr, Warszawa, n. 3, p.14-21 1992.

DZIEWULSKA, Małgorzata. Romantyzm Trzeźwego Wieku. Didaskalia, Pazdziernik, Krakow, Uniwersytet Jagielonski, n. 69, p. 49-52, 2005.

FILIPOWICZ, Halina. Performing Bodies, Performing Mickiewicz: drama as problem in Performance Studies. The Slavic and East European Journal, v. 43, n. 1, p. 1-18, 1999. FLASZEN, Ludwik. Cyrograf [Pacto com o Diabo]. Kraków: Wydawnictwo Literackie, 1974.

GREGORY, Mercedes. Art as Vehicle. [filme], 1989.

GRODZICKI, August. Reżyserzy Polskiego Teatru [Diretores do Teatro Polonês]. Warszawa: Interpress, 1979.

GROTOWSKI, Grotowski. O Praktykowaniu Romatyzmu. Dialog, Warszawa, n. 3, p. 112-120, 1980.

GROTOWSKI, Jerzy. Performer. In: WOLFORD, Lisa; SCHECHNER, Richard (Org.). The Grotowski Sourcebook. New York: Routledge, 1997, p.345-356.

GROTOWSKI, Jerzy. Książe Niezłomny Ryszarda Cieślaka. Notatnik Teatralny, Wiosna/ Lato, n. 10, p. 23-24, 1995. 
GROTOWSKI, Jerzy. On the Genesis of Apocalypsis. TDR: The Drama Review, New York, Mit Press, v. 52, n. 2, p. 40-51, 2008.

HOFFMAN-PIOTROWSKA, Ewa. Mickiewicz-Towiańczyk. Studium myśli. Warszawa: Uniwersytet Warszawski, 2004.

IACOBONI, Franco. Mirroring People: the new science of how we connect with others. New York: Farrar, Straus and Giroux, 2008.

JANION, Maria. Niesamowita Slowiańszczyzna [A Estranha Eslavofilia]. Kraków: Wydawnictwo Literackie, 2006.

JANION, Maria; ZMIGRODZKA, Maria. Romantyzm i Egzystencja. Gdańsk: Słowo/ Obraz Terytoria, 2004.

KOLANKIEWICZ, Leszek. Mały Wielki Wóz. Gdańsk: Słowo/Obraz Terytoria, 2001.

KOLANKIEWICZ, Leszek. Dziady: teatr święta zmarłych. Gdańsk: Słowo/Obraz Terytoria, 1999.

KUHARSKI, Allen. Jerzy Grotowski: ascetic and smuggler. Theater, Durham, Duke University Press, v. 29, n. 2, p. 10-15, 1999.

MAJCHROWSKI, Zbigniew. Kim był Jerzy Grotowski? Odra, Wroclaw, n. 1, p. 40-45, jan. 2000.

MAJCHROWSKI, Zbigniew. Memories of Reduta: Osterwa, Limanowski, Grotowski. In: OSINSKI, Zbigniew. Pamięć Reduty. Osterwa, Limanowski, Grotowski. Gdańsk: Słowo/Obraz Terytoria, 2003. P. 475.

MASLOWSKI, Michał. Gest, Symbol i Rytuały Polskiego Teatru Romantycznego. Warszawa: PWN, 1998.

MICKIEWICZ, Adam. Słowo i czyn [A Palavra e a Ação]. In: MICKIEWICZ, Adam. Wiersze [Poemas]. Warszawa: Czytelnik, 1982, s/p.

MICKIEWICZ, Adam. Dziady. Kraków: TAiWPN Universitas, 1998.

MICKIEWICZ, Adam. Dzieła. Tom xi. In: Literatura Słowiańska: wykłady w College de France, kurs trzeci i czwarty. Warszawa: Czytelnik, 1955. P. 116-117.

MICKIEWICZ, Adam. Dzieła. Warszawa: Czytelnik, 1998.

MONK, Ray. Wittgenstein: the duty of genius. New York: Penguin Books, 1990.

NIETZSCHE, Friedrich. On the Genealogy of Morals. In: KAUFMANN, Walter. Basic Writings of Nietzsche. New York: The Modern Library, 2000. P. 437-600.

NORWID, Cyprian. Bo Piękno na to Jest by Zachwycało/do pracy - praca by się zmartwychwstało. Pisma wierszem i prozą. Warszawa: PIW, 1973.

OSINSKI, Zbigniew. Grotowski: źródła, ispiracje, konteksty. Gdańsk: Słowo/Obraz Terytoria, 1998.

OSINSKI, Zbigniew. Dwa Spokania Moskiewskiej Szkoly Vasiliewa z Grotowskim. In: Pamietnik Teatralny. Warszawa: Instytut Sztuki PAN, 2001. P. 257-264. 
OSINSKI, Zbigniew. Grotowski and the Reduta Tradition. In: ALLAIN, Paul (Org.). Grotowski’s Empty Room. London: Seagul Books, 2009. P. 19-54.

OSINSKI, Zbigniew. Pamięć Reduty. Osterwa, Limanowski, Grotowski. Gdańsk: Słowo/ Obraz Terytoria, 2003.

OSINSKI, Zbigniew. Returning to the Subject: the herritage of Reduta in Grotowski's Laboratory Theatre. The Drama Review, New York, Mit Press, v. 52, n. 2, p. 52-74, 2008.

RAMACHANDRAN, V. S.; BLAKESLEE, Sandra. Phantoms in the Brain. New York: Harper Perennial, 1998.

REPOHL, Roger F. Liturgy as Vehicle. America, n. 24, p. 18-20, set. 1994.

RICHARDS, Thomas. Heart of Practice. Londres: Routledge, 2008.

RICOEUR, Paul. The Model of Text: meaningful action considered as text. New Literary History, Baltimore, Johns Hopkins University, v. 5, n. 1, p. 91-117, 1973.

RUTKOWSKI, Krzysztof. Guślarz na Katedrze, Gazeta Wyborcza, Zbigniew Osiński, Grotowski: Źródła, ispiracje, konteksty. Gdańsk: Słowo, 1998.

SZPOTANSKI, Stanisław. Andrzej Towiański, jego życie i nauka. Warszawa: sem editora, 1938.

TOMCZYK, Wojciech. Bezczelność i talent [Ousadia e Talento]. Teatr, Warszawa, n. 10, p.44, 2006.

WITTGENSTEIN, Ludwig Wittgenstein. Tractatus Logico-Philosophicus. London: Routledge, 2001.

Kris Salata é doutor em Drama e Humanidades pela Stanford University, Estados Unidos da América. É professor na área de Performance na Flórida State University nos EUA. É autor de The Unwritten Grotowski: theory and practice of the encounter, pela Routledge, 2013. Ele possui uma vasta publicação sobre o trabalho de Grotrowski e do Workcenter.

E-mail: kris.salata@gmail.com

Traduzido do original em inglês por Martin Heuser e revisado por Marcelo de Andrade Pereira. Revisão técnica de Tatiana Motta Lima.

Recebido em 28 de agosto de 2012

Aprovado em 02 de dezembro de 2012 